\title{
PHYSIOLOGICAL MATURITY OF SEEDS AND COLORIMETRY OF FRUITS OF Jatropha curcas L. ${ }^{1}$
}

\author{
JOÃO ALEXANDRE LOPES DRANSKI², ARTUR SOARES PINTO JÚNIOR², FÁBIO STEINER ${ }^{3}$, TIAGO ZOZ ${ }^{4}$, \\ UBIRAJARA CONTRO MALAVASI ${ }^{5}$, MARLENE DE MATOS MALAVASI ${ }^{6}$, VANDEIR FRANCISCO GUIMARÃES ${ }^{6}$.
}

\begin{abstract}
The objective was to relate the coloration of fruits of Jatropha curcas L during the maturation process with morphometric (fruits and seeds) and germinative characteristics (seeds). Fruits were collected at various maturation stages from mast trees located in Eldorado/MS, and six maturation stages were visually classified based on fruit's epicarp color. Epicarp digital colorimetry was used to characterize maturation stages in addition to morphometric variables of length and width of fruits and seeds, as well their water content. For determining the physiological potential it was used germination test, emergence velocity index and first count of germination. Results indicated that seeds of $J$. curcas should be harvested when fruit epicarp shows a reading equal or smaller than 82,70 or $65 \mathrm{~nm}$ of red, green or blue scales from a digital color analyzer. Seeds of fruits with that colorimetry can be harvested in virtue of the maxim acumululation of dry mass, water content below $38,5 \%$ and higher physiological potential.
\end{abstract}

Index terms: maturation stage, germination, refractance, morphometry.

\author{
MATURIDADE FISIOLÓGICA DE SEMENTES E COLORIMETRIA \\ DE FRUTOS DE Jatropha curcas L.
}

\begin{abstract}
RESUMO - O estudo objetivou relacionar a coloração de frutos de Jatropha curcas L. durante o processo de maturação com as características morfométricas (frutos e sementes) e germinativas (sementes). Os frutos foram coletados de matrizes em Eldorado/MS, e visualmente classificados em seis estádios de maturação de acordo com a coloração do epicarpo. Para caracterizar a maturidade fisiológica utilizou-se a colorimetria digital assim como as variáveis morfométricas diâmetro e comprimento, assim como a massa seca e o teor de água de frutos e sementes. Para a determinação do potencial fisiológico utilizou-se o teste de germinação, o índice de velocidade de emergência, e o teste da primeira contagem de germinação. Sementes de $J$. curcas devem ser colhidas quando a coloração do epicarpo do fruto for igual ou menor que 82,70 ou $65 \mathrm{~nm}$ das escalas vermelha, verde ou azul de um analisador digital de cor. Sementes de frutos com aquela colorimetria podem ser colhidas em virtude do máximo acúmulo de massa seca, teor de água abaixo de $38,5 \%$, e maior potencial fisiológico.
\end{abstract}

Termos para indexação: estádio de maturação, potencial fisiológico, refratância, morfometria.

\footnotetext{
${ }^{1}$ Submitted in 17/08/2009 Accepted for publication on 22/09/2010.

2 Biologist, Master in Agronomy, Agricultural Science Center, UNIOESTE, Rondon, PR. Schdarship from CNPq, e-mail: joaodranski@ yahoo.com.br, artur_bio@hotmail.com.
}

${ }^{3}$ Agr. MSc. in Agronomy, Agricultural Science Center, UNIOESTE. Rondon-PR, e-mail: fsteiner_agro@hotmail.com
${ }^{4}$ Undergraduate student, Agricultural Science Center, UNIOESTE. Rondon-PR, e-mail: tiago_zoz@hotmail.com

${ }^{5}$ Eng. PhD. Professor Associate, Center for Agricultural Sciences, UNIOESTE. Rondon-PR, e-mail: marlenemalavasi@yahoo.com.br; andeirfg@yahoo.com.br 


\section{INTRODUCTION}

Jatropha curcas L. is a perennial and monoecious species from the Euphorbiaceae family found in several regions of Brazil (Heller, 1996; Beltrão, 2005). The physic nut is a species with great potential for biodiesel production due to the high oil content of seeds (Arruda et al., 2004). Disuniform plantations due to the use of low-quality seeds limit the cultivation expansion in Brazil. Therefore, studies aiming to characterize the maximum seed quality are essential. During the maturation process, seeds go through physical, biochemical and physiological changes influenced by genetic and environmental factors to reach physiological maturity, which offer maximum germination, vigor and dry mass (Marcos Filho, 2005).

In the field, harvesting of forest seeds usually employs physical aspects such as fruit color, size, smell and spontaneous opening as a reference for identifying current practice of harvesting (Sena and Garigliio 1998). In early seed harvesting, the process of maturation is interrupted, which may impair seed quality. The harvesting of seeds with high levels of vigor and germination is of major importance for fast and efficient production of quality seedlings (Carneiro, 1995; Carvalho, 2000; Marcos Filho, 2005). The identification of seed quality related to the color of fruits is important to define the time of harvest (Carvalho and Nakagawa, 2000). Knowledge of the maturation process contributes to the establishment of the ideal time to harvest when seeds have a better physiological quality. Additionally, in early seed harvesting the maturation process is stopped reducing seed quality.

In physic nut, fructification is uneven where growth of last fruits continues after ripening of the first ones in the same inflorescence (Saturnino et al., 2005). Thus, harvest occurs in repeated cycles during the breeding season causing burden on the manpower. Therefore, the classification of fruits of $J$. curcas based on the fruit color and not on the flowering phenology (days after anthesis) has economic and logistical application to obtain seeds of this species.

This study aimed to relate the epicarp color of fruits from Jatropha curcas L. at different maturation stages with morphometric characteristics of fruits and seeds and with seed germination characteristics indicative of physiological maturity of seeds.

\section{MATERIAL AND METHODS}

$J$. curcas fruits were collected in January 2009 in 07 ha of a plantation with a population density of 1333 plants per hectare, located in Eldorado/MS under the geographic coordinates of $54^{\circ} 17^{\prime} 01^{\prime}, \mathrm{W}$ and $23^{\circ} 47$ ' 13 ' $\mathrm{S}$ and 342 meters of mean altitude. The climate of the region is classified according to Köppen as mesothermal subtropical humid, with hot summers (average temperature above $22{ }^{\circ} \mathrm{C}$ ), a tendency toward rainfall concentration, winters with frequent frosts (mean temperature below $18{ }^{\circ} \mathrm{C}$ ), and $1,148 \mathrm{~mm}$ mean annual precipitation. The soil is classified as Dark Red Latosol of sandy texture (Embrapa, 2006).

Thirty kilograms of fruit were collected and visually classified into six maturity stages according to the predominant color with the use of the Munsell color chart (Munsell, 1976) as shown in Figure 1. The first stage was characterized by green fruits, stage 2 by transition fruits from green to yellow pigment, stage 3 predominantly yellow fruits, stage 4 by fruits in transition from yellow to brown pigmentation, stage 5 by mature fruits, and stage 6 dry fruits at the beginning of dehiscence.

Measurements in fruits (pericarp + seed) for each maturity stage involved the analysis of refractance in red, green and blue spectra of 10 fruits using a digital color analyzer (ACR-1023 by Instrutherm ${ }^{\circledR}$ ); quantification of the dry mass of 10 fruits by the oven dry method for $24 \mathrm{~h}$ at $105{ }^{\circ} \mathrm{C}$ with results expressed $\mathrm{mg}$ fruit $^{-1}$; the water content obtained from 10 fruits by the method of oven dry for $24 \mathrm{~h}$ at $105 \pm 3{ }^{\circ} \mathrm{C}$ with values expressed in percentages on a wet basis; and morphometric measurements of length and diameter (the largest central measure perpendicular to the length) of 10 fruits.

Technological parameters used to characterize the physiological maturity of seeds comprised morphometric determinations of seed length and diameter (referring to the largest central perpendicular to the rapheal scar) in 10 seeds; water content obtained from 50 grams of seeds mechanically grounded by the oven dry method for $24 \mathrm{~h}$ at $105 \pm 3{ }^{\circ} \mathrm{C}$ with values expressed in percentage on a wet basis (Brasil, 1992), and the average dry weight of 10 seeds obtained by the oven dry method for $24 \mathrm{~h}$ at 105 ${ }^{\circ} \mathrm{C}$ with results expressed mg seed ${ }^{-1}$.

Germination test was performed based on the germination test for Ricinus communis recommended by the Rules for Seed Analysis (Brasil, 1992) with germination expressed as percentage of normal seedlings obtained 14 days after sowing. The test was conducted in sand substrate, which was sterilized in an autoclave at 120 ${ }^{\circ} \mathrm{C}$ for 15 minutes and moistened with distilled water in amount of $60 \%$ sand field capacity (Brasil, 1992), using 
plastic trays $(42 \times 28 \times 6 \mathrm{~cm})$ under constant temperature of $25^{\circ} \mathrm{C}$ with 12 hours photoperiod in BOD-type germinator $\left(247 \mathrm{G}\right.$ Fanen $\left.{ }^{\circledR}\right)$ with 25 seeds per replicate. As vigor tests we also evaluated first count germination (percentage of normal seedlings 7 days after sowing) and emergence velocity index (EVI) according to Maguire (1962).

\begin{tabular}{|c|c|c|c|}
\hline $\begin{array}{l}\text { Maturration } \\
\text { stage }\end{array}$ & Epicarp color & $\begin{array}{c}\text { Visual } \\
\text { Characterization } \\
\end{array}$ & Munsell chart* \\
\hline 1 & & Green Fruit & 7,5 GY 6/6 \\
\hline 2 & & $\begin{array}{l}\text { Fruit ar the beginning } \\
\text { of yellow pigmentation }\end{array}$ & 2,5 GY 5/10 \\
\hline 3 & & $\begin{array}{l}\text { Predominantly yellow } \\
\text { fruit }\end{array}$ & $5 \mathrm{Y} 8 / 10$ \\
\hline 4 & & $\begin{array}{l}\text { Fruit at the beginning } \\
\text { of brown pigmentation }\end{array}$ & $5 \mathrm{Y} 8 / 8$ \\
\hline 5 & & Mature fruit & $7 \mathrm{YR} 4 / 2$ \\
\hline 6 & & $\begin{array}{l}\text { Dry fruit ar the } \\
\text { beginning of dehiscence }\end{array}$ & $5 Y R 3 / 2$ \\
\hline
\end{tabular}

FIGURE 1. Color of physic nut fruits (Jatropha curcas L.) at different maturation stages. * Munsell color charts for plants tissues.

Values expressed in percentages were transformed into square root arcsine $\mathrm{x} / 100$. Data were checked for normality of residual distribution and variance homogeneity, followed by analysis of variance using the statistical software SISVAR ver. 5.0 (Ferreira, 2000). The experimental design was a completely randomized with treatments consisting of six stages of fruit ripening with four replicates. Treatment means were compared by the Tukey test at $5 \%$ probability.

\section{RESULTS AND DISCUSSION}

The quantification of fruit refractance with the digital color analyzer (Table 1) showed statistical differences (P $<0.01)$ for the different fruit maturation stages in the three colour scales of the instrument. The readings on the red, blue and green scales showed higher mean values when reached stages 2 and 3, indicating that fruit's pericarp was expressed a predominantly yellow color, followed by a reading reduction towards stages 5 and 6 , in which no significant difference existed between maturation stages in all scales of the instrument.

Digital quantification of colors lines by monochrome scale enables to distinguish areas subject to color variations. In this context, the greatest variation of means in relation to maturity stages allowed to classify fruits with greater repeatability. Refractance values in scales of red and green of the digital color analyzer allowed a better differentiation in maturation stages of fruits compared to the refractance numerical values in the blue scale (Table 1).

Similar behavior was observed by Effendi et al. (2009) in unripe, ripe and dried fruits of $J$. curcas with refractance values of red, green and blue scales via digitized images. The digital colorimeter has advantages of visual acuity, training of technical personnel and computer manipulation to separate maturation stages of fruits. Sena and Gariglio (1998) and Germaque et al. (2002) reported that color change of fruits is a good indicator to assist in identifying the harvest stage of several species. 
TABLE 1. Average refractance values of fruits of Jatropha curcas L. obtained with a digital color analyzer.

\begin{tabular}{|c|c|c|c|}
\hline \multirow{3}{*}{ Maturation stage } & \multicolumn{3}{|c|}{ Refractance scale } \\
\hline & Red & green & blue \\
\hline & \multicolumn{3}{|c|}{----------------------------------- nm ----------------------------------- } \\
\hline 1 & $239.40 \mathrm{~b}$ & $262.80 \mathrm{~b}$ & $156.50 \mathrm{~b}$ \\
\hline 2 & $454.70 \mathrm{a}$ & $402.50 \mathrm{a}$ & $193.40 \mathrm{ab}$ \\
\hline 3 & $494.80 \mathrm{a}$ & $396.20 \mathrm{a}$ & $201.30 \mathrm{a}$ \\
\hline 4 & $232.10 \mathrm{~b}$ & $165.60 \mathrm{c}$ & $103.50 \mathrm{c}$ \\
\hline 5 & $82.90 \mathrm{c}$ & $70.40 \mathrm{~d}$ & $65.30 \mathrm{~d}$ \\
\hline 6 & $75.70 \mathrm{c}$ & $64.50 \mathrm{~d}$ & $59.00 \mathrm{~d}$ \\
\hline MSD & 67.02 & 61.37 & 37.23 \\
\hline $\mathrm{CV}(\%)$ & 19.2 & 20.4 & 21.7 \\
\hline
\end{tabular}

Averages followed by the same letter in columns are not statistically different among themselves at $5 \%$ by the Tukey test. 1 . Green fruit; 2 . Fruit at the beginning of yellow pigmentation 3. Predominantly yellow fruit, 4 . Fruit at the beginning of brown pigmentation, 5 . mature fruit; 6 . Dry fruit at the beginning of dehiscence.

The criterion of fruit color as an indicator of physiological seed quality was recommended to harvest seeds of Ricinus communis when fruits were brown colored (Silva et al., 2009) as well as for several species as reported by Aquino et al. (2006) in Peltophorum dubium, for Machaerium brasiliense by Guimarães and Barbosa (2007), and by Aguiar et al., (2007) for Caesalpinia echinata, when fruits of these species were in transition from green to brown preceding the spontaneous opening.

Therefore, the harvesting of physic nut based on fruit color, quantified by a digital instrument will facilitate the development of appropriate machinery for fruit selection by color, allowing the obtaining of seeds of that oleaginous with maximum physiological potential.

Physical characteristics of fruits of $J$. curcas in the six maturation stages (Table2) indicated that the maximum length of fruits is reached at stage 2, while the diameter progressed up to stage 3. Subsequent to those stages, there was reduction in morphometric variables. The length and diameter ranged from $33.0 \mathrm{~mm}$ and $28.3 \mathrm{~mm}$ in fruits classified as stage 1 , to $27.2 \mathrm{~mm}$ and $21.4 \mathrm{~mm}$ for fruits classified as stage 6 , respectively. These figures show that both fruit length and diameter were reduced with the maturation process as a function of water loss. Similar results were reported by Silva (2002) with the fruit size of Cnidosculus phyllacantus which reached maximum values 53 days after flowering, when fruits were entirely yellow. Saturnino et al. (2005) reported that the diameter of $J$. curcas when ripe ranged between 15 $30 \mathrm{~mm}$, similarly to those measured in this study.

TABLE 2. Length and diameter of fruits and seeds of Jatropha curcas L. depending on the maturation stages.

\begin{tabular}{|c|c|c|c|c|}
\hline \multirow{3}{*}{ Maturation stage } & \multicolumn{2}{|c|}{ Fruit } & \multicolumn{2}{|c|}{ Seed } \\
\hline & Length & Diameter & Length & Diameter \\
\hline & \multicolumn{4}{|c|}{---------------------------------------- $\mathrm{mm}$--------------------------------------- } \\
\hline 1 & $33.01 \mathrm{a}$ & $28.26 \mathrm{a}$ & $20.72 \mathrm{a}$ & $8.92 \mathrm{a}$ \\
\hline 2 & $32.48 \mathrm{ab}$ & $28.06 \mathrm{a}$ & $20.95 \mathrm{a}$ & $8.87 \mathrm{a}$ \\
\hline 3 & $31.96 \mathrm{bc}$ & $27.30 \mathrm{a}$ & $20.59 \mathrm{a}$ & $8.85 \mathrm{a}$ \\
\hline 4 & $31.11 \mathrm{c}$ & $26.31 \mathrm{~b}$ & $19.95 \mathrm{~b}$ & $8.86 \mathrm{a}$ \\
\hline 5 & $28.44 \mathrm{~d}$ & $24.14 \mathrm{c}$ & $19.57 \mathrm{~b}$ & $8.74 \mathrm{a}$ \\
\hline 6 & $27.16 \mathrm{e}$ & $21.39 \mathrm{~d}$ & $18.89 \mathrm{c}$ & $8.75 \mathrm{a}$ \\
\hline MSD & 0.96 & 0.98 & 0.55 & 0.36 \\
\hline $\mathrm{CV}(\%)$ & 1.39 & 1.67 & 1.21 & 1.79 \\
\hline
\end{tabular}

Averages followed by the same letter in columns are not statistically different among themselves at $5 \%$ by the Tukey test. 1 . Green fruit; 2 . Fruit at the beginning of yellow pigmentation 3. Predominantly yellow fruit, 4. Fruit at the beginning of brown pigmentation, 5. mature fruit; 6 . Dry fruit at the beginning of dehiscence. 
The diameter of seeds was not significantly changed in maturing stages of fruits $(\mathrm{P}>0.05)$. However, higher values for length were reached when fruits showed mostly yellow. Seeds obtained from fruits at stage 1 measured $20.72 \mathrm{~mm}$ and $892 \mathrm{~mm}$, while those obtained by fruits at stage 6 measured $18.89 \mathrm{~mm}$ and $8.75 \mathrm{~mm}$ in length and diameter, respectively (Table 2). Saturnino et al. (2005) reported $J$. curcas seeds $15-20 \mathrm{~mm}$ long and $8-13 \mathrm{~mm}$ in diameter which are similar measures to this test. Studies on seeds morphology are necessary due to the importance in botanical identification, ecological aspects, as well as the propagation of species.

Fruit dry weight (Table 3) did not change significantly after fruit pigmentation (stage 2). There was an average gain of $314 \mathrm{mg}$ fruit $^{-1}$ from stage 1 to stage 2 , where it remained constant until dehiscence. Therefore, the dry matter of fruits was not an effective indicator of physiological maturity in seeds of $J$. curcas.

TABLE 3. Water content and dry matter in fruits and seeds of Jatropha curcas L. depending on maturation stages of fruit.

\begin{tabular}{|c|c|c|c|c|}
\hline \multirow{2}{*}{ Maturation stage } & \multicolumn{2}{|c|}{ Fruit } & \multicolumn{2}{|c|}{ Seed } \\
\hline & Water content & Dry mass & Water content & Dry mass \\
\hline & ---- \% ---- & -- mg fruit ${ }^{-1}-$ & ---- \% ---- & -- mg seed $^{-1}--$ \\
\hline 1 & $83.48 \mathrm{a}$ & $387 \mathrm{~b}$ & $67.51 \mathrm{a}$ & $220 \mathrm{c}$ \\
\hline 2 & $78.63 \mathrm{~b}$ & $701 \mathrm{a}$ & $40.77 \mathrm{~b}$ & $291 \mathrm{ab}$ \\
\hline 3 & $76.87 \mathrm{bc}$ & $728 \mathrm{a}$ & $39.44 \mathrm{~b}$ & $299 \mathrm{ab}$ \\
\hline 4 & $73.94 \mathrm{c}$ & $685 \mathrm{a}$ & $39.37 \mathrm{~b}$ & $294 \mathrm{ab}$ \\
\hline 5 & $66.10 \mathrm{~d}$ & $643 \mathrm{a}$ & $38.50 \mathrm{~b}$ & $302 \mathrm{a}$ \\
\hline 6 & $13.58 \mathrm{e}$ & $635 \mathrm{a}$ & $14.48 \mathrm{c}$ & $259 \mathrm{bc}$ \\
\hline MSD & 3.75 & 99.6 & 8.97 & 40.6 \\
\hline $\mathrm{CV}(\%)$ & 2.55 & 7.04 & 9.98 & 6.51 \\
\hline
\end{tabular}

Averages followed by the same letter in columns are not statistically different among themselves at $5 \%$ by the Tukey test. 1. Green fruit; 2 . Fruit at the beginning of yellow pigmentation 3. Predominantly yellow fruit, 4. Fruit at the beginning of brown pigmentation, 5. mature fruit; 6 . Dry fruit at the beginning of dehiscence.

The seeds of physic nut are characterized by three distinct phases concerning dry mass (Table 3). From the green fruits to those in transition to yellow color, there was an average biomass gain of $71 \mathrm{mg}$ seed $^{-1}$ when they weighed $291 \mathrm{mg} \mathrm{seed}^{-1}$, which then remained statistically equal until maturity (stage 5 ), followed by the third phase with mass reduction to $259 \mathrm{mg} \mathrm{seed}^{-1}$ due to deterioration.

Seed dry weight when combined with other features was a good indicator of physiological maturity for Torresia acreana (Firmino et al., 1996), for Dalbergia nigra (Martins and Silva, 1997), for Cedrela fissilis (Corvello et al., 1999), for Cnidosculus phyllacanthus for Mimosa caesalpiniifolia by Alves (2005), for Peltophorum dubium by Aquino et al. (2006), for Machaerium brasiliense by Guimarães and Barbosa (2007), and for Caesalpinia echinata by Aguiar et al. (2007). However, for Barbosa et al. (1992) fruit and seed dry biomass of Copaifera langsdorffii were not good indicators of physiological maturity.

The water content of fruits and seeds suffered gradual decrease with advancing maturity (Table 3 ). The water content in seeds decreased from stage 1 to stage 2 whose value remained statistically unchanged until the stage 5 of maturation. The water content (14.48\%) in seeds of $J$. curcas at stage 6 is the result of less restriction to water diffusion into the atmosphere as a function of dehiscence. Similar behavior was obtained by Martins et al. (2008) studying Jacaranda cuspidifolia. The same authors stated that seeds with maximum germination and vigor are those harvested from ripe fruits with brown color, whose seeds showed gradual dehydration process culminating at levels below 24.4\% water content. Firmino et al. (1996), Martins and Silva (1997), Silva (2002), Marcos Filho (2005) and Iossi et al. (2007) stated that water content when associated with other characteristics highlights the 
physiological condition of seeds.

Seeds of $J$. curcas extracted from fruits at stage 1 did not germinate. From stage 4 characterized by the onset of brown pigmentation, there was a significant increase in seed germination from $29 \%$ to $66 \%$ and $74 \%$ at stages 5 and 6, respectively (Figure 2). Emergence speed index and first count germination reached maximum values with seeds collected from fruits classified as stages 5 and 6. Seeds harvesting of J.curcas based on fruits color measured by a digital instrument will facilitate the development of machinery suitable for processing seeds of that plant.

According to Kaushik (2003), the maximum seed physiological potential of $J$. curcas was achieved in yellow fruits which recorded $89 \%$ of germination with lower results obtained from seeds of green and dry fruits. For Dagar et al. (2004), the increase in seed germination was positively correlated with fresh weight, with higher germination values been achieved in seeds with a mass exceeding $300 \mathrm{mg}$. Germaque et al. (2002) studying the ideal harvesting time of purple-ipe (Tabebuia impetiginosa) seeds reported higher germination and vigor of seeds harvested in the early dehiscence of fruits when they showed green color with purple spots, and seeds of green-yellow-brown color with water content of $69.02 \%$ and $50.98 \%$ in fruits and seeds, respectively.
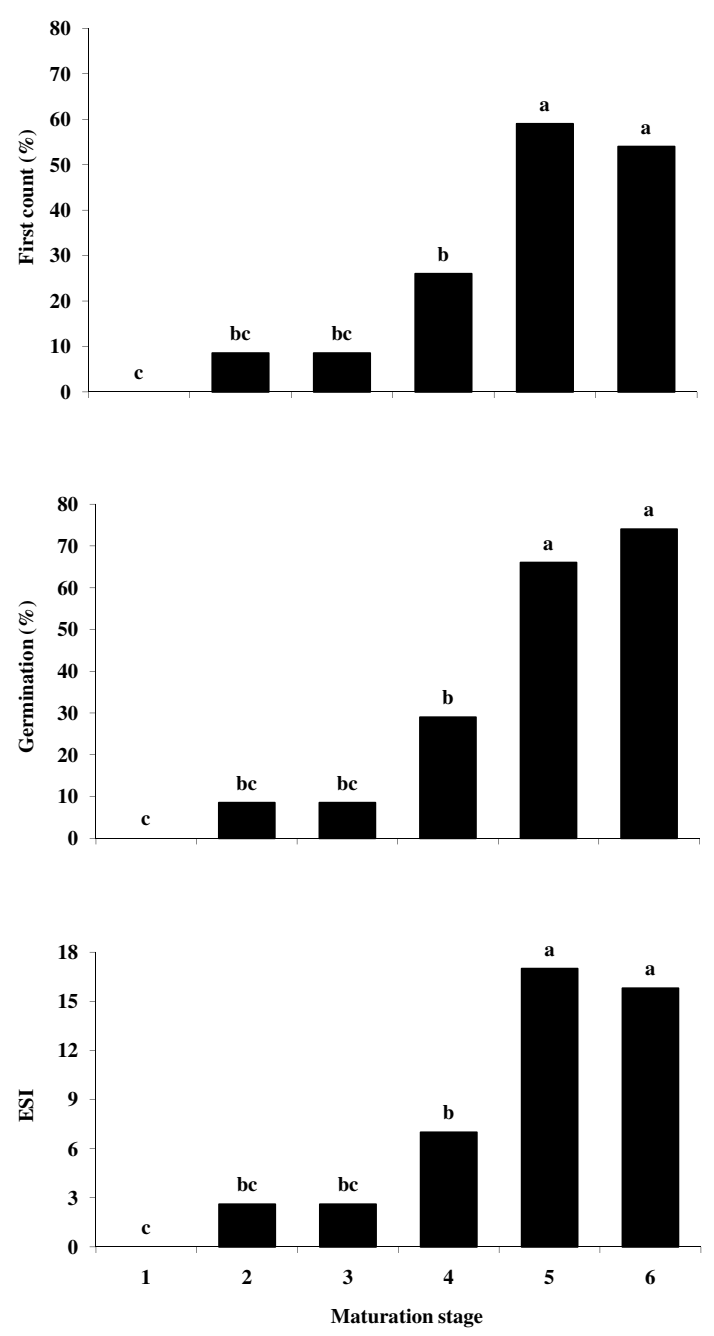

FIGURE 2. First count of germination, germination percentage and emergence speed index (ESI) of seeds of Jatropha curcas $\mathbf{L}$. at different maturation stages. Marechal Cândido Rondon/PR, 2009. Means compared by the Tukey test at 5\% probability. 1. Green fruit; 2. Fruit at the beginning of yellow pigmentation 3. Predominantly yellow fruit, 4. Fruit at the beginning of brown pigmentation, 5. Mature fruit; 6. Dry fruit at the beginning of dehiscence. 


\section{CONCLUSIONS}

Seeds of Jatropha curcas L. with germination higher than $60 \%$ and IVE higher than 15 must be harvested from ripe fruits with fully brown color of epicarp corresponding to the classification 7 YR 4/2 of the Munsell color chart, or refractance values equal to or lower than 82,70 or $65 \mathrm{~nm}$ in the red, green and blue scales respectively, obtained with a digital colorimeter. Fruits with epicarp presenting the aforementioned colorimetric characteristics have maximum accumulation of dry biomass, water content below $38.5 \%$, and seeds with physiological maturity.

\section{ACKNOWLEDGEMENTS}

We express our thanks to the Rural Biodiesel S/A by the availability of plant material, and the $\mathrm{CNPq}$ for financial support.

\section{REFERENCES}

AGUIAR, F.F.A.; PINTO, M.M.; TAVARES, A.R.; KANASHIRO, S. Maturação de frutos de Caesalpinia echinata Lam. Pau-Brasil. Revista Árvore, v.31, n.1, p.1-6, 2007.

ALVES, E.U.; SADER, R.; LUCENA, R.; ALCÂNTARA, B.; ALVES, A.U. Maturação fisiológica de sementes de Sabiá. Revista Brasileira de Sementes, v.27, n.5, p.1-8, 2005.

AQUINO, N.F. BORTOLINI, M.; CAMPAGNOLO, M.A.; IGNÁCIO, V.L.; KOPPER, A.C.; MALAVASI, M.M. Dormêcia de sementes de Peltophorum dubium (Sprengel.) Taubert colhidas em diferentes estádios de desenvolvimento. Scientia Agraria Paranaensis, v.5, n.2, p.31-37, 2006.

ARRUDA, F.P.; BELTÃO, N.E.M.; ANDRADE, A.P.; PEREIRA, W.E; SEVERINO, L.S. Cultivo de pinhãomanso (Jatropha curcas L.) como alternativa para o semiárido nordestino. Revista Brasileira de Oleaginosas e Fibrosas, v.8, n.1, p.789-799, 2004.

BARBOSA, J.M.; AGUIAR, I.B.; SANTOS, S.R.G. Maturação de sementes de Copaifera langsdorffii Desf. Revista do Instituto Florestal, v.4, n.3, p.665-674, 1992.

BELTRÃO, N.E.M. Agronegócio das oleaginosas no Brasil. Informe Agropecuário, v.26, p.44-78, 2005.

BRASIL. Ministério da Agricultura e Reforma Agrária. Secretária Nacional de Defesa Agropecuária. Departamento
Nacional de Defesa Vegetal. Coordenação de Laboratório Vegetal. Regras para análise de sementes. Brasília, DF, 1992. 365p.

CARNEIRO, J.G.A. Produção e controle de qualidade de mudas florestais. Curitiba: UFPR/UENF/FUPEF, 1995. 451p.

CARVALHO, P.E.R. Produção de mudas de espécies nativas por sementes e a implantação de povoamentos. In: GALVÃO, A.P.M. (Org.). Reflorestamento de propriedades rurais para fins produtivos e ambientais. Um guia prático para ações municipais e regionais. Colombo: Embrapa Florestas, 2000. p.151-174.

CARVALHO, N.M.; NAKAGAWA, J. Sementes: ciência, tecnologia e produção. 2.ed. Jaboticabal: FUNEP, 2000. $588 \mathrm{p}$.

CORVELLO, W.B.V.; VILLELA, F.A.; NEDEL, J.L.; PESKE, S.T. Maturação fisiológica de sementes de cedro (Cedrela fissilis Vell.). Revista Brasileira de Sementes, v.21, n.2, p.23-27, 1999.

DAGAR, J. C.; BHAGWAN H.; KUMAR Y. Seed germination studies of Salvadora persica and Jatropha curcas. Indian Journal of Forestry, v.27, n.3, p.283-289, 2004.

EFFENDI, Z. RAMLI,; R.; GHANI, J.A.; YAAKOB, Z. Development of Jatropha curcas color grading system for ripeness evaluation. European Journal of Scientific Research, v.30, n.4, p.662-669, 2009.

EMPRESA BRASILEIRA DE PESQUISA AGROPECUÁRIA - EMBRAPA.Centro Nacional de Pesquisa de Solos. Sistema Brasileiro de Classificação de Solos. 2.ed. Rio de Janeiro: Embrapa, 2006. 306p.

FERREIRA, D.F. Análise estatística por meio do SISVAR para Windows versão 4.0. In: REUNIÃO ANUAL DA REGIÃO BRASILEIRA DA SOCIEDADE INTERNACIONAL DE BIOMETRIA, 45., São Carlos, 2000. Anais... São Carlos: UFScar: 2000. p.255-258.

FIRMINO, J.L.; SANTOS, D.S.B.; SANTOS FILHO, B.G. Características físicas e fisiológicas de sementes de cerejeira (Torresia acreana Ducke) quando as sementes foram coletadas do chão ou do interior dos frutos. Revista Brasileira de Sementes, v.18, n.1, p.28-32, 1996.

GERMAQUE, R.C.R.; DAVIDE, A.C.; FARIA, J.M.C. Indicadores de maturidade fisiológica de sementes de ipêroxo (Tabebuia impetiginosa (Mart.) Standl.). Cerne, v.8, n.2, p.84-91, 2002.

GUIMARÃES, D.M.; BARBOSA, J.M. Coloração 
dos frutos como índice de maturação para sementes de Machaerium brasiliense Vogel (Leguminosae - Fabaceae). Revista Brasileira de Biociências, v.5, n.2, p.567-569, 2007.

HELLER, J. Physic nut (Jatropha curcas L.): Promoting the conservation and use of underutilized and neglected crops. Roma, IBPGR, 1996. 66p.

IOSSI, E.; SADER, R.; VITTIMORO, F.; BARBOSA, J.C. Maturação fisiológica de sementes de Phoenix roebelenii O'Brien. Revista Brasileira de Sementes, v.29, n.1, p.147-154, 2007.

KAUSHIK, N. Effect of capsule maturity on germination and seedling vigour in Jatropha curcas. Seed Science and Technology, v.31, n.2, p.449-454, 2003.

MAGUIRE, J.D. Speeds of germination-aid selection emergence and vigor. Crop Science. v.2, p.176-7, 1962.

MARCOS FILHO, J. Fisiologia de sementes de plantas cultivadas. Piracicaba: FEALQ, 2005. 495p.

MARTINS, C.C.; BELISARIO, L.; TOMAZ, C.A.; ZUCARELI, C. Condições climáticas, características do fruto e sistema de colheita na qualidade fisiológica de sementes de jacarandá. Revista Árvore, v.32, n.4, p.627632,2008 .
MARTINS, S.V.; SILVA, D.D. Maturação e época de colheita de sementes de Dalbergia nigra (Vell.) Fr. All. ex Benth. Revista Brasileira de Sementes, v.19, n.1, p.9699, 1997.

MUNSELL, A.H. Munsell color charts for plants tissues. Macbeth. Division of Margen Corporation. Baltimore: 1976.

SATURNINO, H.M.; PACHECO, D.D.; KAKIDA, J.; TOMINAGA, N.; GONÇALVES, N.P. Cultura do pinhãomanso (Jatropha curcas L.). Informe Agropecuário, v.26, n.229, p.44-78, 2005.

SENA, C.M.; GARIGLIO, M.A. Sementes florestais: colheita, beneficiamento e armazenamento. Brasília, DF: IBAMA, 1998. 27p.

SILVA, L.M.M. Maturação fisiológica de sementes de Cnidosculus phyllacanthus Pax \& K. Hoffm. 2002. $61 \mathrm{f}$. Tese (Doutorado em Agronomia) - Faculdade de Ciências Agrárias e Veterinárias, Universidade Estadual Paulista, Jaboticabal, 2002.

SILVA, L.B.; MARTINS, C.C.; MACHADO, C.G.; NAKAGAWA, J. Estádios de colheita e repouso póscolheita dos frutos na qualidade de sementes de mamoneira. Revista Brasileira de Sementes, v.31, n.1, p.50-59, 2009. 